\title{
Assessment of High Enthalpy Geothermal Resources and Promising Areas of Chile
}

\author{
Diego Aravena $^{\mathrm{a}, \mathrm{b}, *}$, Mauricio Muñoz ${ }^{\mathrm{a}, \mathrm{b}}$, Diego Morata ${ }^{\mathrm{a}, \mathrm{b}}$, Alfredo Lahsen ${ }^{\mathrm{a}, \mathrm{b}}$, \\ Miguel Ángel Parada ${ }^{\mathrm{a}, \mathrm{b}}$, Patrick Dobson ${ }^{\mathrm{c}}$ \\ ${ }^{a}$ Centro de Excelencia en Geotermia de los Andes (CEGA), Facultad de Ciencias Físicas y \\ Matemáticas, Universidad de Chile, Santiago, Chile. \\ ${ }^{b}$ Departamento de Geología, Facultad de Ciencias Físicas y Matemáticas, Universidad de \\ Chile, Santiago, Chile. \\ ${ }^{c}$ Earth Sciences Division, Lawrence Berkeley National Laboratory, Berkeley, California, \\ USA.
}

\begin{abstract}
This work aims to assess geothermal power potential in identified high enthalpy geothermal areas in the Chilean Andes, based on reservoir temperature and volume. In addition, we present a set of highly favorable geothermal areas, but without enough data in order to quantify the resource. Information regarding geothermal systems was gathered and ranked to assess Indicated or Inferred resources, depending on the degree of confidence that a resource may exist as indicated by the geoscientific information available to review. Resources were estimated through the USGS Heat in Place method. A Monte Carlo approach is used to quantify variability in boundary conditions. Estimates of total Indicated resource are confined to 3 geothermal systems; Apacheta, El Tatio and Tolhuaca, yielding a total value of $228 \pm 154$ MWe. The estimates of the total Inferred resources for Chile include 6 geothermal systems and yield a total value of $431 \pm 321$ MWe. Standard deviation reflects the high variability of reservoir specific parameters for each system. A set of 65 favorable geothermal areas are proposed as the most likely future development targets. Eight of them, have initial exploration results that suggest they are highly favorable targets as
\end{abstract}

\footnotetext{
${ }^{*}$ Corresponding author

Email addresses: daravena@ing.uchile.cl (Diego Aravena), maumunoz@ing.uchile.cl (Mauricio Muñoz)
}

Preprint submitted to Geothermics

August 15, 2015

(C) 2015. This manuscript version is made available under the Elsevier user license http://www.elsevier.com/open-access/userlicense/1.0/ 
potential geothermal resources.

Keywords: Geothermal power potential, high enthalpy, Chilean Andes, USGS Heat in Place, Monte Carlo.

3

\section{Introduction}

Early geothermal exploration in Chile began in 1921, when an Italian technical group from Larderello drilled two wells of about 70-80 $\mathrm{m}$ depth at El Tatio geothermal field (Tocchi, 1923). Systematic exploration resumed in 1968 as a result of a joint project by the Chilean Development Corporation (Corporación de Fomento de la Producción, CORFO) and the United Nations Development Program (UNDP) (Lahsen, 1976). In addition, geothermal exploration was carried out by the Japan International Cooperation Agency (JICA) in Puchuldiza (Lahsen, 1978; JICA, 1979; Letelier, 1981) and Surire (Cusicanqui, 1979). Since then, basic exploration, drilling and feasibility studies have been conducted sporadically, mainly by Universidad de Chile (Lahsen, 1976, 1988), the National Geological Survey (Servicio Nacional de Geología y Minería, SERNAGEOMIN) (Hauser, 1997; Peréz, 1999), and the National Oil Company (Empresa Nacional del Petróleo, ENAP). By early 2000, a geothermal law was enacted providing the framework for the exploration and development of geothermal energy in Chile. Henceforth, comprehensive efforts to assess geothermal potential have been made by public entities and private companies (e.g. Lahsen et al., 2010, and references therein). During the first half of 2011, the Chilean Government founded the Andean Geothermal Center of Excellence (Centro de Excelencia en Geotermia de Los Andes, CEGA), a Fondap-Conicyt project hosted at Universidad de Chile, aimed to improve geothermal knowledge and promote its use in the Andean countries. This work is part of a nationwide geothermal evaluation carried on since then (e.g. Sánchez et al., 2011; Aravena \& Lahsen, 2012, 2013).

Early resource assessments considered a gradient of $45^{\circ} \mathrm{C} / \mathrm{km}$ in the Chilean Plio-Quaternary volcanic belt, yielding $1.85 \times 10^{22} \mathrm{~J}$ of thermal energy stored in water above $150^{\circ} \mathrm{C}$ for depths less than $5 \mathrm{~km}$ (Aldrich et al. 1981). Later 
on, Lahsen (1986) calculated values on the order of 16,000 MWe for 50 years contained in fluids with a temperature over $150{ }^{\circ} \mathrm{C}$, and at a depth less than $3 \mathrm{~km}$. Updated estimates of the geothermal potential in northern Chile yield values between 400 and 1,300 MWe (Procesi, 2014). In southern Chile estimates vary between 600 and 1,400 MWe (Lahsen et al., 2010, Aravena \& Lahsen, 2012).

This work was initiated to provide a realistic estimate of accessible geothermal resources associated with high enthalpy $\left(>200^{\circ} \mathrm{C}\right)$ reservoirs in the Chilean Andes, with emphasis on geological, geophysical and geochemical evidence constraining each geothermal system. To do this, we gathered and ranked published information regarding available geothermal exploration and Quaternary volcanic features establishing a hierarchy of Measured, Indicated and Inferred geothermal resources. To assess the geothermal resources of Chile, the USGS Heat in Place method is applied. Although this study does not produce absolute values of power potential, it does provide a systematic manner with which to compare prospects based on the available/published information. In addition, we present a set of areas with a favorable geothermal setting whose published information is still considered deficient.

\section{Volcanic and geothermal setting}

The Andean volcanic arc includes over 200 potentially active volcanoes, and at least 12 giant caldera/ignimbrite systems (Lee et al., 2010), occurring in four separate segments referred to as the Northern (NVZ; $\left.2^{\circ} \mathrm{N}-5^{\circ} \mathrm{S}\right)$, Central $(\mathrm{CVZ}$; $14-28^{\circ} \mathrm{S}$ ), Southern (SVZ; $\left.33-46^{\circ} \mathrm{S}\right)$, and Austral (AVZ; $49-55^{\circ} \mathrm{S}$ ) Volcanic Zones (Fig. 1]. Volcanism results from subduction of the Nazca and Antarctic oceanic plates below South America (Muñoz \& Stern, 1988; Cembrano et al. 2007). The country contains more than 300 geothermal areas located along the Chilean Andes, associated with Quaternary volcanism. The main geothermal systems occur in the extreme northern $\left(17-28^{\circ} \mathrm{S}\right)$ and central-southern part $\left(33-46^{\circ} \mathrm{S}\right)$ of Chile. In areas where Quaternary volcanism is absent, such as along the Andean volcanic gaps $\left(28-33^{\circ} \mathrm{S}\right.$ and $\left.46-48^{\circ} \mathrm{S}\right)$, as well as in the 

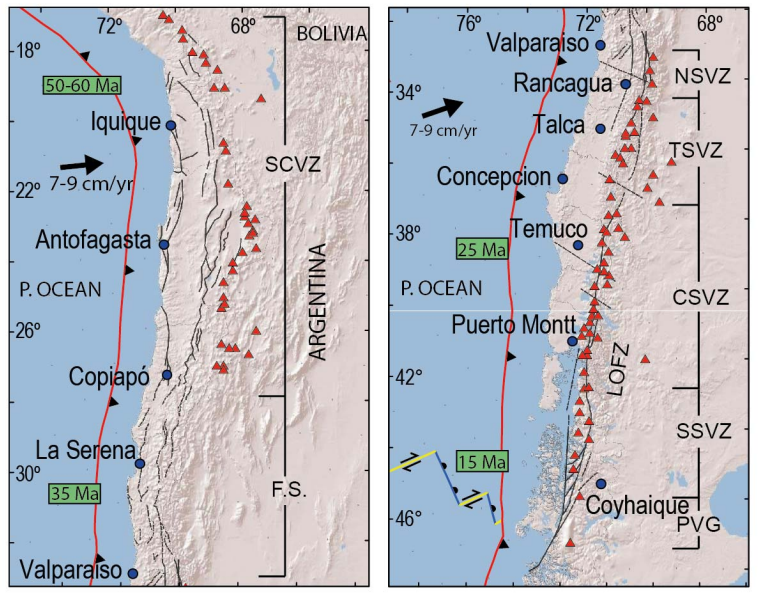

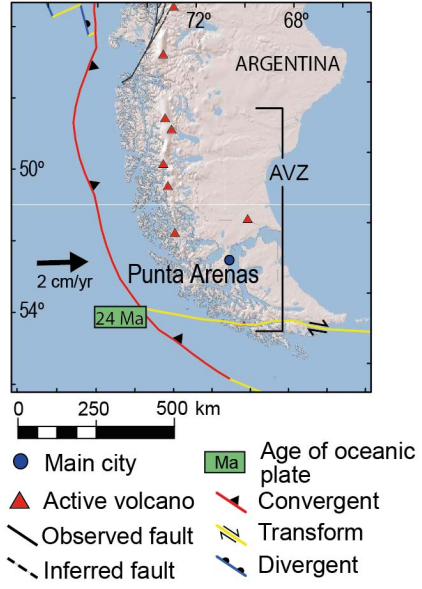

Figure 1: Tectonic setting, regional scale faults and active volcanoes of the Chilean Andes. SCVZ, Southern Central Volcanic Zone; F.S., Flat Slab; NSVZ, Northernmost SVZ; TSVZ, Transitional SVZ; CSVZ, Central SVZ; SSVZ, Southern SVZ; PVG, Patagonian Volcanic Gap; AVZ, Austral Volcanic Zone. Main fault systems of the SCVZ modified from Cembrano et al. (2007). Flat Slab structures modified from SERNAGEOMIN (2003). Regional structures in the SVZ modified from SERNAGEOMIN (2003); Rosenau et al. (2006); Cembrano \& Lara (2009), and references therein. Age of oceanic plate after Tebbens et al. (1997).

\section{Methodology}

\subsection{Selection and ranking of geothermal areas}

A major challenge in geothermal resource assessment lies in quantifying

${ }_{66}$ the size and thermal energy of a reservoir. This work follows other Heat in

${ }_{67}$ Place geothermal resource studies in using the terminology adopted by Muffler 
\& Cataldi (1978) for the subdivision of the geothermal resource base. Geothermal resources are subdivided according to increasing geological confidence into Inferred, Indicated, and Measured categories. Areas where reservoir features have been constrained indirectly by geophysics (dimensions) and fluid geochemistry (reservoir temperature), but whose reservoir has not been reached by wells are ranked as Inferred. Areas where the reservoir has been confirmed by exploratory wells are ranked as Indicated. If the geothermal play has wells with a proven deliverability, it is ranked as Measured.

Through the analysis of geological, geochemical and geophysical data, and using a GIS weighted overlay superposition method, Aravena \& Lahsen (2013) generated a nationwide map of geothermal favorability. This map, along with data gathered in this work, was used to establish two additional categories of geothermal plays: i) highly probable resource areas for regions where geophysical surveys indicate the existence of a geothermal reservoir or fluid geothermometry suggest high temperatures associated with a deep reservoir; and ii) interest areas for regions with extensive surface geothermal features and high temperature discharges. Interest areas include zones with discharges of lower temperature, yet whose context has a research concern, such as an unknown heat source in areas with no active volcanism (Fig 2). Most of these areas lack available data needed to properly quantify the resource.

\subsection{USGS Heat in Place method for reservoir constrained assessment}

To assess the geothermal resources of Chile, a reformulation of the USGS Heat in Place method is applied (Garg \& Combs, 2015). This model involves estimating the thermal energy available in a liquid dominated reservoir to calculate recoverable electric power (Williams et al., 2008, and references therein). A Monte Carlo approach is used to quantify variability of boundary conditions. After 100,000 iterations, the resulting power output is fitted to a probability distribution to assess the $10 \%, 50 \%$ and $90 \%$ confidence intervals, referred to as P90, P50 and P10, respectively. Fig. 3 shows the fit of results to a BirnbaumSaunders distribution for the Tolhuaca geothermal system. 

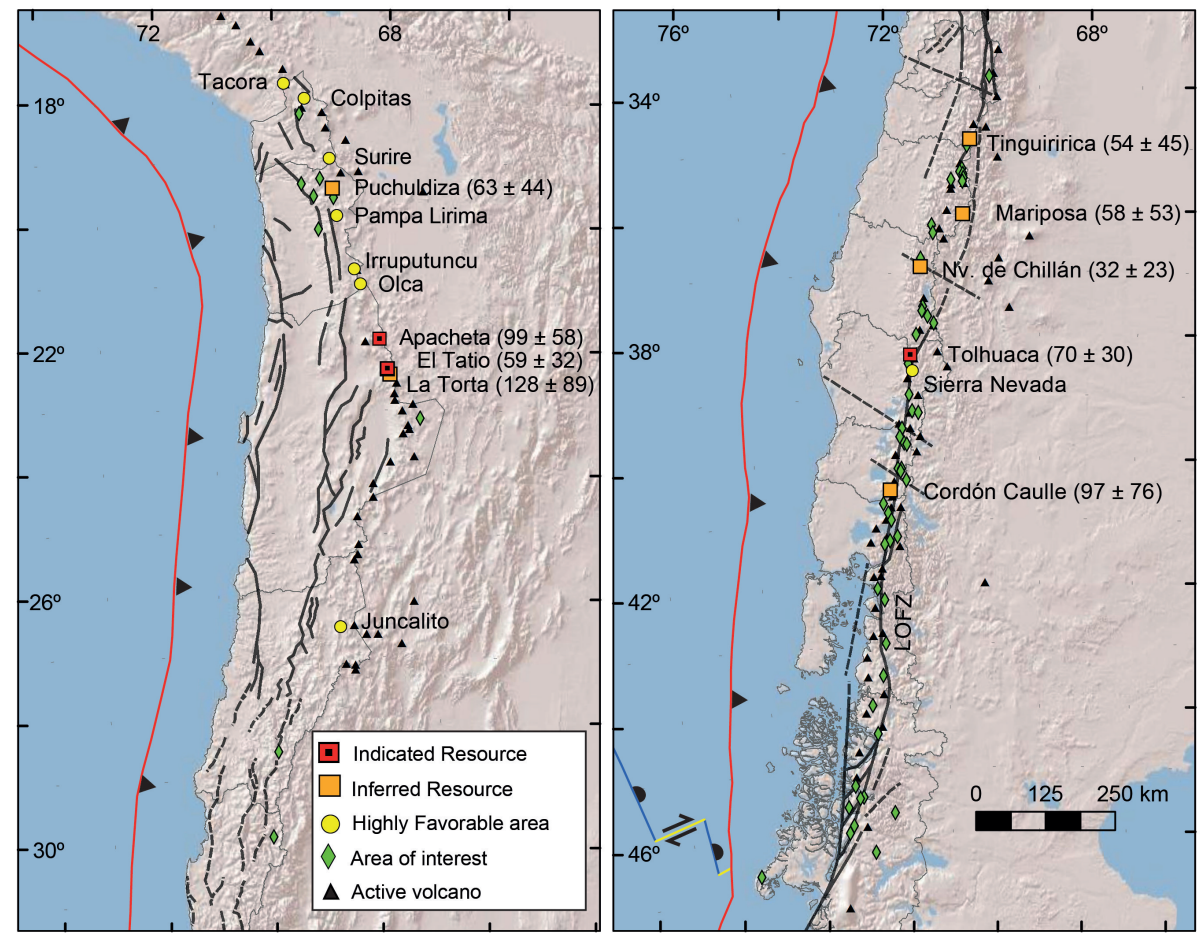

Figure 2: Main geothermal areas in Chile. Indicated and Inferred resources are displayed with name and assessment results. Highly probable and interest areas are depicted in Table 3 and 4 respectively. Regional structures as in Fig. 1

The USGS Heat in Place volumetric method was used in early geothermal resource estimations in the 1970's (Nathenson, 1975, White \& Williams, 1975 Muffler \& Cataldi, 1978, Muffler, 1979), and later improved based on updated empirical factors, and specific power cycles (e.g. Lovekin, 2004, Williams et al. 2008 Zarrouk \& Moon, 2014 Garg \& Combs, 2015). This method states that the electric power potential for an identified geothermal system can be determined by the reservoir thermal energy, the amount of thermal energy that can be extracted from the reservoir at the wellhead, the specific power cycle, and the efficiency for the electric power conversion of the wellhead thermal energy (Garg \& Combs, 2015, and references therein). Once mass flux and its thermal properties at the wellhead are determined, the thermodynamic and economic 

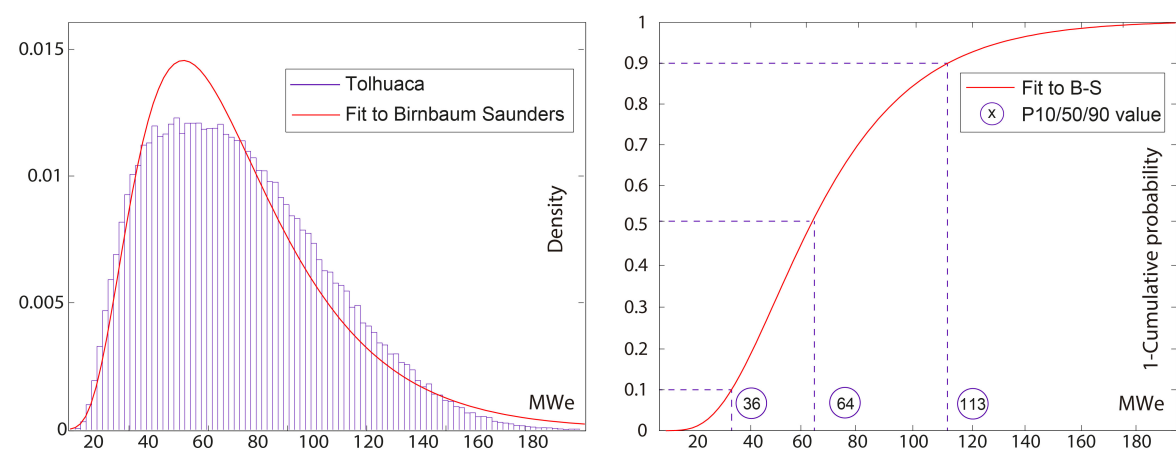

Figure 3: Results after 100,000 Monte-Carlo iterations for the Tolhuaca geothermal System. Left, power output results (bins) and fit (red line) to a Birnbaum-Saunders probability distribution function (PDF); right, cumulative distribution function (CDF) showing P10, P50 and P90 intervals of confidence.

constraints for conversion to electric power can be calculated (e.g. DiPippo 2012b; Zarrouk \& Moon, 2014).

11 The reservoir thermal energy, $q_{R}[\mathrm{~J}]$, is calculated as follows:

$$
q_{R}=\overline{\rho c} V\left(T_{R}-T_{r}\right)
$$

Here, $\overline{\rho c}$ is the volumetric heat capacity in the reservoir $\left[\mathrm{J} / \mathrm{m}^{3} \mathrm{~K}\right], V$ is the reservoir volume $\left[\mathrm{m}^{3}\right], T_{R}$ is the reservoir temperature, and $T_{r}$ is a reference or abandonment temperature (Garg \& Combs, 2015). Regarding the reservoirs temperatures, we assessed single flash cycles, for all geothermal plays. Therefore, for a single flash power plant, the abandonment temperature is given by the saturation temperature corresponding to the separator pressure ( 5 bar, $151.831^{\circ} \mathrm{C}$ ). The geothermal recovery factor $R_{g}$ is defined as the ratio of the heat recovered at the wellhead $q_{w}$, to the heat stored in the reservoir $q_{R}$.

$$
R_{g}=\frac{q_{w}}{q_{R}}
$$

In the above equation $R_{g}$ is the geothermal recovery factor [dimensionless]. Updated values of the geothermal recovery factors include 0 to 0.2 , the latter value is believed to be the maximum reliable value based on global experience 
with production from liquid dominated reservoirs (Garg \& Combs, 2010). If the well drilling and testing has shown adequate well productivity, it is justified to assume a non-zero minimum value (say 0.05) for the geothermal recovery factor (Garg \& Combs, 2015). In addition, we carry out a sensitivity test for the power output as a function of the geothermal recovery factor, encompassing values from the published literature.

Combining Eqs. (1) and (2), the heat recovered at the wellhead $q_{w}$, can be expressed by the following expression:

$$
q_{w}=\alpha\left(T_{R}-T_{r}\right)
$$

Here:

$$
\alpha=R_{g} V \overline{\rho c}
$$

Assuming isenthalpic flow in the wellbore and neglecting the work required to raise the water, the enthalpy of produced fluid at the well head $h_{w}$, is equal to that of liquid water at reservoir temperature.

$$
h_{w}=h_{w}\left(T_{R}\right)
$$

The amount of fluid produced at the wellhead $m_{w}$, is given by:

$$
m_{w}=\frac{q_{w}}{\left(h_{w}-h_{r}\right)}
$$

Here, $h_{r}$ is the enthalpy of liquid water at the reference temperature $T_{r}$. Substituting from Eq. (3) into Eq. (6), there follows:

$$
m_{w}=\alpha \frac{\left(T_{R}-T_{r}\right)}{\left(h_{w}-h_{r}\right)}
$$

Neglecting kinetic or potential effects, the maximum energy output per unit mass of the substance $e$ is given by (DiPippo, 2008):

$$
e=h-h_{e x}-T_{e x K}\left(s-s_{e x}\right)
$$


Here, $h$ and $s$ denote the enthalpy and entropy of the substance (e.g., steam) at turbine inlet conditions with temperature $T, T_{\text {exK }}$ is the absolute exit temperature (Kelvin), and $s_{e x}$ is the entropy of the liquid phase (water), at the exit temperature. For mass $m$ of substance the available work is therefore given by:

$$
W_{A}=m e=m\left(h-h_{e x}-T_{e x K}\left(s-s_{e x}\right)\right)
$$

In the case of single flash power plant, it is assumed that the produced fluid with reservoir temperature at the wellhead is separated at the separator temperature $T_{s e p}$. The separated brine is reinjected into the reservoir, and the steam is used to generate power. The mass of the fluid produced at the wellhead is given by Eq. 7 with $T_{r}=T_{\text {sep }}$. The steam fraction of the produced fluid is:

$$
m_{s t m}=m_{w} \frac{\left(h_{w}\left(T_{R}\right)-h_{w}\left(T_{s e p}\right)\right)}{h_{g l}\left(T_{s e p}\right)}
$$

Here, $h_{g l}\left(T_{s e p}\right)$ denotes the heat of vaporization. Combining Eqs. 7 and 10 there follows:

$$
m_{s t m}=\alpha \frac{\left(T_{R}-T_{s e p}\right)}{h_{g l}\left(T_{s e p}\right)}
$$

Substituting $m_{\text {stm }}$ for $m$ in Eq. 9, the available work for the single slash case is given by:

$$
W_{\text {Aflash }}=\alpha \frac{\left(T_{R}-T_{\text {sep }}\right)}{h_{g l}\left(T_{\text {sep }}\right)}\left(h_{s t m}\left(T_{\text {sep }}\right)-h_{w}\left(T_{c}\right)-T_{c K}\left(s_{s t m}\left(T_{s e p}\right)-s_{w}\left(T_{c}\right)\right)\right)
$$

In the above equation, $T_{c}$ denotes the condenser temperature (assumed to be $40^{\circ} \mathrm{C}$; (Garg \& Combs, 2015)), and $T_{c K}$ is the absolute condenser temperature.

A conservative value for the electrical conversion efficiency $\eta_{u}$ of $70 \%$ to $80 \%$ is proposed by Garg \& Combs (2015), thus we used $75 \%$ for calculations. In addition, a load factor $f_{\text {load }}$ of 0.95 is considered. Therefore, the electric power for a given period of years is determined as follows:

$$
W_{e}=\frac{W_{\text {Aflash }} \eta_{u}}{Y f_{\text {load }}}
$$


Finally, for calculation simplicity, the years $(Y)$ in Eq. 13 are expressed in seconds $[\mathrm{s}]$.

\section{Results}

\subsection{Inferred and Indicated resources}

\subsubsection{Boundary conditions}

Parameters required for the calculation are summarized in Tab. 1. Reservoir specific parameters must be established individually for each geothermal system since they constrain the geometry and temperature/enthalpy of the Indicated or Inferred reservoir. Common parameters remain constant for all systems. For instance, for the Tolhuaca geothermal prospect, reservoir specific parameters were extracted from the geological setting and geothermal surveys performed in the area (Tab. 1).

Variability in the estimates is accommodated through a Monte Carlo simulation approach. For each system, we determine most likely (m.l.), minimum (min) and maximum $(\max )$ values for reservoir temperature, thickness, and area. Those values are used to generate triangular (min, m.l. and max) and uniform (min, max) probability distributions. Parameters with only a most likely value (m.l.) remain constant for each Monte Carlo iteration (Tab. 1).

\subsubsection{Geological, geochemical and geophysical constraints}

We considered 9 geothermal prospects that have enough information to estimate their power potential. The first three systems presented below are ranked as Indicated (Apacheta, El Tatio and Tolhuaca). The remaining 6 systems are ranked as Inferred (Puchuldiza, La Torta, Tinguiririca, Mariposa, Nevados de Chillán, and Cordón Caulle). El Tatio/La Torta is considered as two separated systems even though they probably share a deep reservoir (see details in text).

\section{Apacheta/Cerro Pabellón geothermal system}

The Cerro Pabellón geothermal power generation project, located in the Apacheta geothermal concession in Antofagasta region, Chile, is owned by a 


\begin{tabular}{lccc}
\hline Reservoir specific parameters & min & m.l. & $\max$ \\
\hline Area $\left(k m^{2}\right)$ & 4 & - & 8 \\
Thickness $(\mathrm{km})$ & 1 & - & 1.4 \\
Temperature $\left({ }^{\circ} \mathrm{C}\right)$ & 250 & 280 & 300 \\
\hline USGS Heat in Place parameters & & & \\
\hline Volumetric Heat Capacity $\left(k J / m^{3} \mathrm{~K}\right)$ & - & 2700 & - \\
Abandonment Temperature $\left({ }^{\circ} \mathrm{C}\right)$ & - & 151.831 & - \\
${ }^{1}$ Geothermal Recovery Factor $(\%)$ & 0 & - & 20 \\
Condenser Temperature $\left({ }^{\circ} \mathrm{C}\right)$ & - & 40 & - \\
Electric Conversion Efficiency $(\%)$ & - & 75 & - \\
Plant Load Factor $(\%)$ & - & 95 & - \\
Plant or Project Life $($ years $)$ & - & 30 & - \\
\hline
\end{tabular}

Table 1: Parameters required for the calculation of the electric generation capacity using the USGS volumetric Heat in Place method for the Tolhuaca geothermal system. Constraints are shown as Minimum (min), most likely (m.l.) and maximum (max) values for reservoir specific and common parameters. ${ }^{1}$ In case well drilling and testing, that confirm geothermal resource, the minimum value of geothermal recovery factor is $5 \%$.

joint project between Enel Latin-American (Chile) Ltd., and the National Oil Company (ENAP). The project, already approved by the environmental authorities and currently under development, involves the construction and operation of a geothermal power plant with installed capacity of 48 MWe (ENEL, 2012). This graben-hosted system has four deep wells, placing it into the Indicated Resource category. The thickness of the reservoir is constrained by the convective regime in wells CPE-1 (880 m) and CPE-2 (1120 m), starting at 900 and $820 \mathrm{~m}$ depth, respectively. Wells CPE-4 and CPE-3 show a conductive regime (ENEL, 2012). Horizontal extension of the reservoir will be assessed as parallel and perpendicular to the graben, following the conceptual model proposed by Urzua et al. (2002), Fig. 4. The minimum horizontal extension of the reservoir is given by the distance between wells $\left(4 \mathrm{~km}^{2}\right)$. Maximum extension in the NE-SW orientation is given by the projected distance between the graben main 
faults at the depth of the reservoir. In the NW-SE direction, maximum extension will be considered as the linear projection of thickness vs distance for wells CPE-1 and CPE-2 ( $\left.5 \times 5 \mathrm{~km}^{2}\right)$. Minimum and maximum temperatures of the reservoir are reached in wells $\mathrm{CPE}-2\left(212{ }^{\circ} \mathrm{C}\right)$ and $\mathrm{CPE}-1\left(256^{\circ} \mathrm{C}\right)$, consistent with gas geothermometry estimates of around $250^{\circ} \mathrm{C}$ reported by Urzua et al. (2002).

\section{El Tatio/La Torta geothermal system}

The El Tatio geothermal prospect is one of the largest geothermal fields of South America (Fig. 5). This geothermal system comprises 85 fumaroles, 62 hot springs, 40 geysers, 5 mud volcanoes and extensive sinter terraces, scattered over an area of $30 \mathrm{~km}^{2}$ (Tassi et al., 2005). The La Torta geothermal field is located at the southern extension of the eastern edge of the El Tatio graben. Geophysical evidence suggests that El Tatio and La Torta share the same deep reservoir. According to the interpreted resistivity structure, the El Tatio geothermal system must be at the edge (out-flow) of the main geothermal reservoir located in the La Torta prospect, which contains the main up-flow zone (Cumming et al. 2002). We use a conservative approach, assessing the areas as separate reservoirs with different constraints and resource categories.

The geometry of the El Tatio reservoir is constrained by exploratory and exploitation wells, and therefore qualifies as an Indicated system. The minimum and maximum reservoir thickness is $150 \mathrm{~m}$ and $600 \mathrm{~m}$, respectively, as constrained by well data (Lahsen \& Trujillo, 1976; Sarmiento et al., 2010). The average thickness of the Puripicar and Río Salado ignimbrite is $430 \mathrm{~m}$, considered as the most likely value (Lahsen \& Trujillo, 1976). The minimum resource area is constrained by wells where convective heat transfer zones are observed $11.5 \mathrm{~km}^{2}$, and the maximum areal extent is constrained by early geophysical surveys, where $30 \mathrm{~km}^{2}$ was estimated through vertical electrical sounding interpretation (Lahsen \& Trujillo, 1976). A minimum temperature of $213^{\circ} \mathrm{C}$ was measured in well 8 and the maximum temperature of $260^{\circ} \mathrm{C}$ was encountered in well 7 (Lahsen \& Trujillo, 1976); these values are selected as the minimum and maximum reservoir temperatures, respectively. A most likely value of $250{ }^{\circ} \mathrm{C}$ 


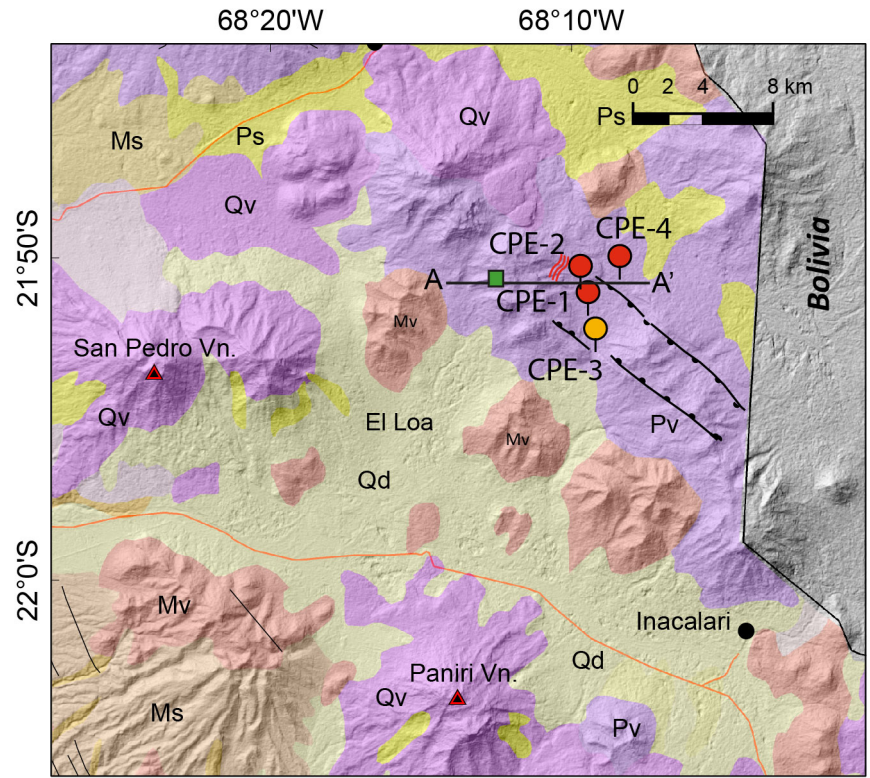

\section{Geology}

$\square$ Qd: Quaternary deposits Qv: Quaternary volcanism Pv: Pliocene volcanism Ps: Pliocene sedimentary rocks Mv: Miocene volcanism Ms: Miocene sedimentary rocks Inferred fault

- Normal fault — Main Road

\section{Geothermal Features}

A Active volcano

S Shallow well

Deep well

II) Fumarole

Altered area

//// Resistivity

$251020(\mathrm{ohm} / \mathrm{m})$

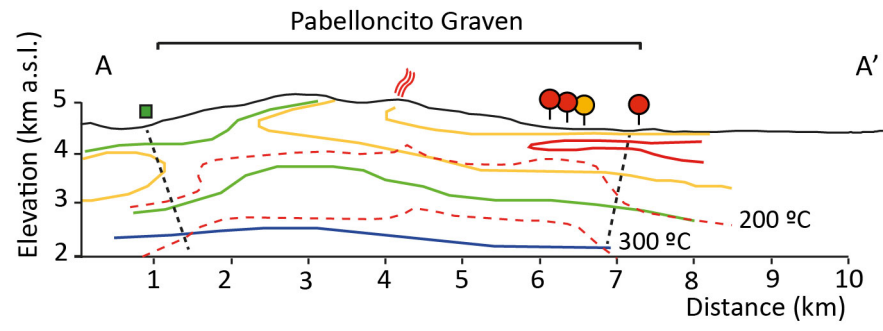

Figure 4: Geological map of the Apacheta area. Geology modified from Ramírez \& Huete (1981). Bottom; squematic cross section with geothermal features and well location. Projected faults, MT and temperature interpretation modified from Urzua et al. (2002). 
was selected for calculations.

The main reservoir at the La Torta prospect was constrained by geochemical and geophysical evidence. Cumming et al. (2002) delineates a $20 \mathrm{~km}^{2}$ low resistivity anomaly $(<10 \Omega \mathrm{m})$ under the El Tatio volcanic chain. This value will be considered as the most likely, with a variability of $5 \mathrm{~km}^{2}$, therefore a minimum areal extent of $15 \mathrm{~km}^{2}$ and a maximum of $25 \mathrm{~km}^{2}$ were considered. Minimum thickness is $650 \mathrm{~m}$, based on well data (Sarmiento et al., 2010). Maximum thickness can reach 2,000 m based on stratighraphic data and MT survey results (Cumming et al., 2002). The minimum temperature is $240^{\circ} \mathrm{C}$, based on temperatures reached by wells located on the southern edge of the El Tatio prospect. The maximum temperature is constrained by gas geothermometry wich suggests that the temperatures in the El Tatio-La Torta deep geothermal reservoir reaches up to $270^{\circ} \mathrm{C}$ (Tassi et al., 2010).

\section{Tolhuaca geothermal system}

The Tolhuaca geothermal system was confirmed by a flow test of one of the deep wells, and thus can be considered as an Indicated resource. As proposed by Melosh et al. (2012), we consider a two level reservoir with steam and steam-heated waters at shallow depths, and a deep liquid reservoir below. For simplicity, they will be treated as individual reservoirs in closed systems. Between 200 and $600 \mathrm{~m}$ depth, temperatures in Tol-2 are above the hydrostatic $1.1 \mathrm{wt} \%$ gas boiling point for depth (BPD) curve, suggesting steam-dominated conditions nearby; similar conditions were encountered in Tol-1 between 200 and $400 \mathrm{~m}$ depth, consistent with a convective thermal regime (Melosh et al. 2012). Most wells reach $150-200^{\circ} \mathrm{C}$ at $500 \mathrm{~m}$ depth (considered as min. and max. respectively). The results for the shallow reservoir show power production values of less than $1 \mathrm{MWe}$, and therefore are not considered as commercial when compared to the deep reservoir. The deep well, Tol-3, encountered a liquid-dominated reservoir from 1,100 to $2,500 \mathrm{~m}$ depth at $300^{\circ} \mathrm{C}$, consistent with the high temperature propylitic alteration zone $\left(>250{ }^{\circ} \mathrm{C}\right)$ observed in the other wells (Iriarte, 2013, Fig. 6). These values will be used as the maximum thickness and temperature respectively. Minimum horizontal extent of 


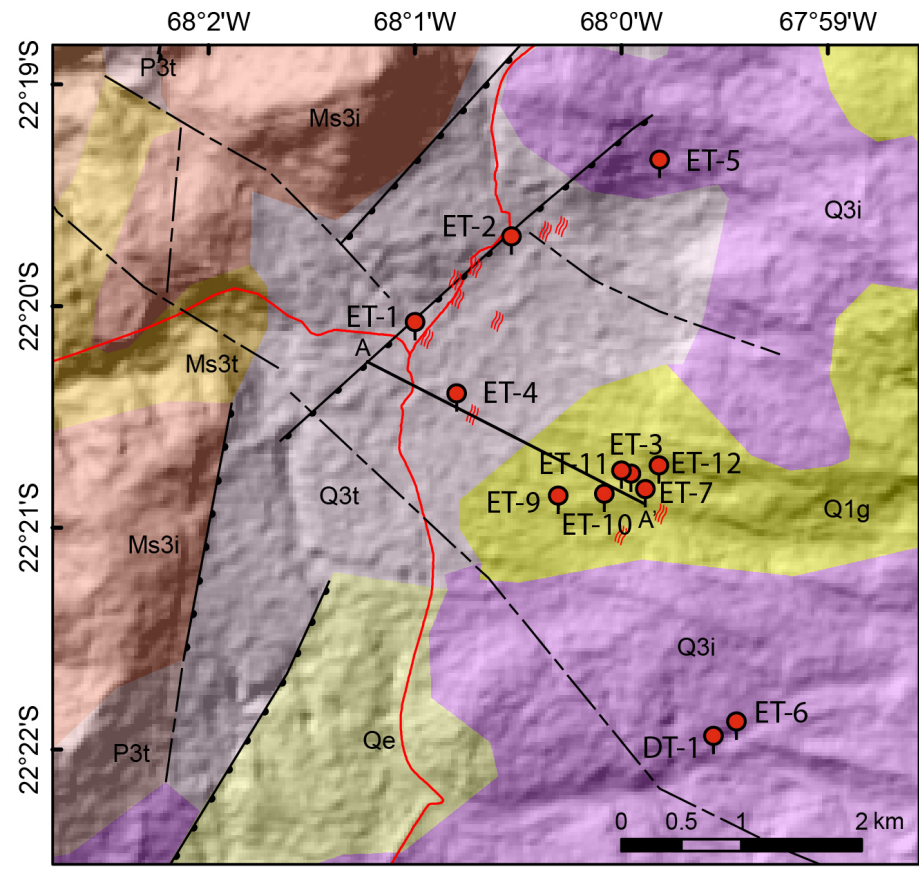

Geology

Qe: Quaternary eolian deposits Q3i: Quaternary volcanism Q3t: Quaternary tuff

Plt1: Pleisticene El Tatio ignimbrite

Plt2: Pleistocene Tucle volcanic group

P3t: Puripicar ignimbrite

Ms3i: Miocene Río Salado volcanic group

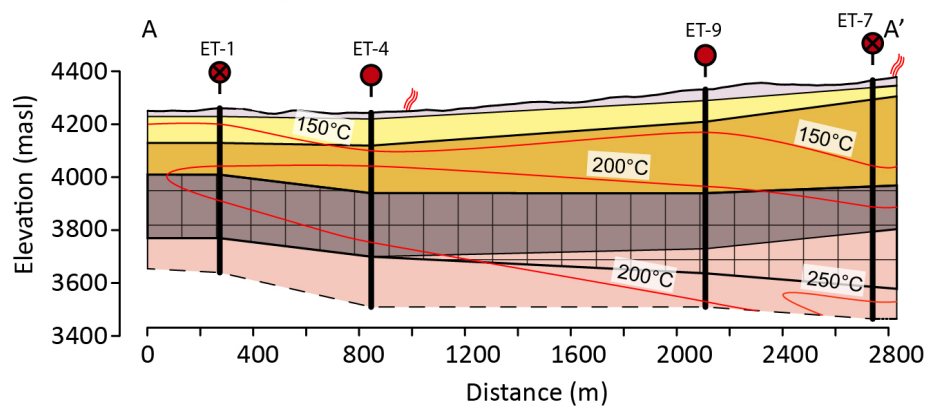

Figure 5: Geological map of El Tatio area. Borehole data from Lahsen \& Trujillo (1976); Sarmiento et al. (2010). Bottom; geological cross section with geothermal features and well location. 
the reservoir is constrained by a low resistivity conductive anomaly associated with a $7-8 \mathrm{~km}^{2}$ clay cap, identified by Melosh et al. (2012).

\section{Puchuldiza geothermal system}

The Puchuldiza geothermal prospect is characterized by extensive superficial geothermal features such as thermal springs, fumaroles and mineral alteration (Tassi et al. 2010). The minimum areal extent is $10 \mathrm{~km}^{2}$ which is delineated by shallow exploratory wells $\left(<600 \mathrm{~m}\right.$ deep, reaching $\left.170{ }^{\circ} \mathrm{C}\right)$. Vertical electrical soundings indicate a potential maximum areal extent of $28 \mathrm{~km}^{2}$ (JICA, 1979 Lahsen et al., 2010). Geological and geophysical surveys indicate a reservoir thickness range between 600-1000 m (Ortiz et al., 2008, and references therein). A minimum reservoir temperature of $200^{\circ} \mathrm{C}$ was measured in a $1000 \mathrm{~m}$ deep exploratory well, whereas the most likely and maximum reservoir temperature is expected to reach $250^{\circ} \mathrm{C}$ and $270^{\circ} \mathrm{C}$, respectively, based on Na-K and Na-K-Ca geothermometry (Ortiz et al. 2008).

\section{Tinguiririca geothermal system}

The tinguiririca geothermal project is located $\sim 150 \mathrm{~km}$ SW from Santiago within the main Andean Range, on the western flank of the Tinguiririca Volcanic Complex. The Tinguiririca reservoir volume is constrained by the potential upflow zone identified by Clavero et al. (2011), a subtle concave shaped conductive anomaly at 2,500 m.a.s.l interpreted by Lira (2011) as a deep geothermal reservoir, although this preliminary conclusion is subject to further exploration. This surface covers between 5 and $25 \mathrm{~km}^{2}$; the minimum and maximum thickness of the reservoir are $500 \mathrm{~m}$ and $1,000 \mathrm{~m}$, respectively, accounting for the distance between the $10-75$ and $10-120(\Omega \mathrm{m})$ intervals respectively $(<10 \Omega \mathrm{m}$ is interpreted to be a low resistivity clay altered cap). The lower temperature of the reservoir is given by the temperature reached in well Pte- $1,210^{\circ} \mathrm{C}$. The maximum temperature is estimated to be $300{ }^{\circ} \mathrm{C}$, based on geothermometry by Clavero et al. (2011); Vázquez et al. (2014).

\section{Mariposa geothermal system}

The Mariposa Geothermal System (MGS) is located $\sim 300$ km south of Santiago in the TSVZ. It lies within an area characterized by extensive Quaternary 


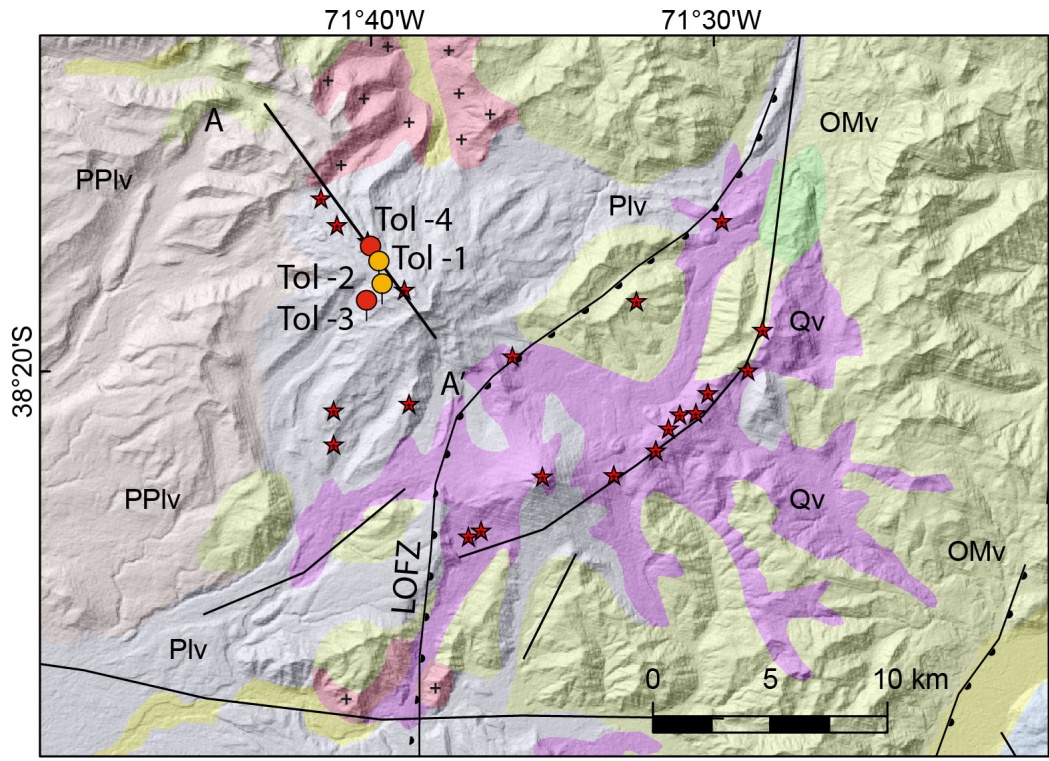

\section{Geology}

Qv Holocene volcanism

Pleistocene volcanoclastic assemblage

PPIV Pliocene-Pleistocene basalt and tuff

OMv Oligocene-Miocene volcanosedimentary assemblage

${ }^{+}+{ }_{+}^{+}$Mi: Miocene Granitoid

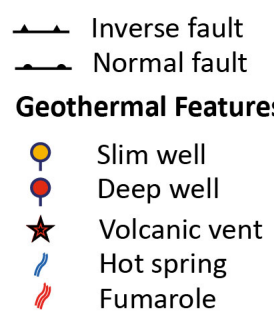

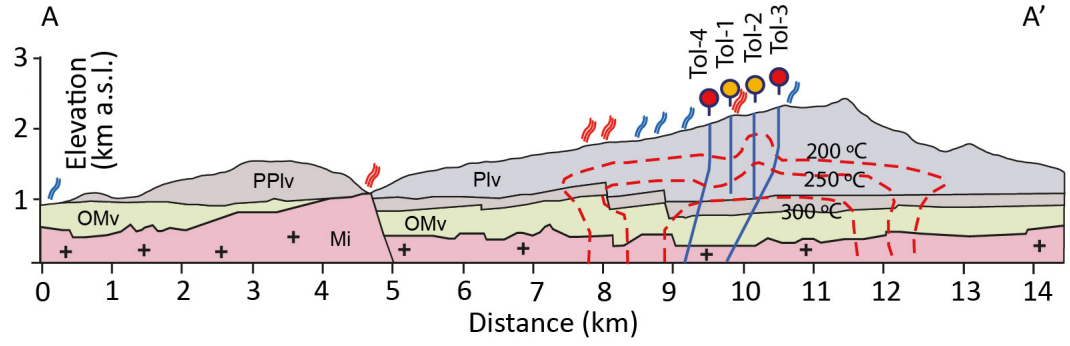

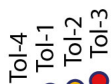

Figure 6: Geological map of Tolhuaca area (modified from Emparán et al. 1997, SERNAGEOMIN 2003 Rojas et al. 2014) including, quaternary volcanic vents (modified from Moreno \& Gardeweg 1989) and main structures Rosenau et al. 2006 Pérez et al. and references within); Geographic coordinates WGS84, zone $19^{\circ} \mathrm{S}$. Bottom; Schematic cross section with geothermal features, wells and temperature interpretation after Iriarte (2013). LOFZ, Liquie Ofqui Fault Zone. 
volcanism associated with the Maule Volcanic Complex and the Tatara-San Pedro-Pellado volcanic complex. A volumetric resource assessment performed by SKM yielded 320 MWe for a plant life of 30 years. In this assessment, the reservoir area was constrained by a 23 to $27 \mathrm{~km}^{2}$ conductive anomaly obtained during the 2009 and 2010 MT surveys (Hickson et al. 2011). In this case we consider a minimum value of $9 \mathrm{~km}^{2}$, accounting for the two principal upflow areas inferred by Hickson et al. (2011), this value can be extended to a less conservative $23 \mathrm{~km}^{2}$ as interpreted from data presented by Hickson et al. (2011). Reservoir thickness is taken from the base of the conductor (600-1,000 m depth) to a depth that can be readily accessed by drilling, and up to the thickness of the Oligocene-Miocene units that host the reservoir, yielding values ranging from 1 to $2 \mathrm{~km}$ thick. The minimum reservoir temperature is constrained by the well MP- $1\left(210^{\circ} \mathrm{C}\right)$, maximum temperature $\left(300^{\circ} \mathrm{C}\right)$ is based on gas geothermometry by Hickson et al. (2011).

\section{Nevados de Chillán geothermal system}

The Nevados de Chillán geothermal area is associated with a $13 \mathrm{~km}$ long NW trending volcanic chain comprising calderas, polygenetic volcanoes and flank volcanoes. Hot springs discharge over $500 \mathrm{l} / \mathrm{s}$ of sulfate-bicarbonate waters with temperatures of up to $70^{\circ} \mathrm{C}$, equal to a heat loss of about $100 \mathrm{MWt}$ (Sepúlveda \& Lahsen, 2003). The reservoir volume is constrained by a concave shaped resistivity anomaly interpreted from an MT survey performed by the National Geothermal Company (Empresa Nacional de Geotermia, ENG) (ENG, 2007). The size of the anomaly ranges from 6 to $15 \mathrm{~km}^{2}$. The reservoir has an estimated thickness varying from 500 to $1,000 \mathrm{~m}$, with minimum and maximum temperatures of $220^{\circ} \mathrm{C}$ and $260^{\circ} \mathrm{C}$, based on temperatures reached by well Nieblas-1 and gas geothermometry respectively (ENG, 2007). The shallow reservoir reached by NCh-1 is considered too small for electric generation and therefore will not be included in the assessment.

\section{Cordón Caulle geothermal system}

The Cordón Caulle geothermal area is located in a $15 \mathrm{~km}$ long, $5 \mathrm{~km}$ wide, flat-topped volcano-tectonic depression, bounded to the northwest by the $8.5 \mathrm{~km}$ 
wide caldera of the Cordillera Nevada, and to the southeast by the 2,240 $\mathrm{m}$ high Puyehue volcano (Sepúlveda et al. 2007, and references therein). The minimum reservoir area is inferred from the distribution of thermal springs, $\sim 8 \mathrm{~km}^{2}$, on the other hand the maximum area may be expanded to $20 \mathrm{~km}^{2}$, as suggested by gravity and MT data (Sepúlveda, 2005, Rojas, 2013). Based on stratigraphic relationships, gravity, MT, and seismic data, the thickness for the potential reservoir was estimated between 500 to 2,000 m (Sepúlveda, 2005, Rojas, 2013). Gas geothermometry yields temperatures from 240 to $300{ }^{\circ} \mathrm{C}$ (Sepúlveda et al. 2007).

\subsubsection{Inferred and Indicated resource}

Results for the Heat in Place method are summarized in Table 2, along with the standard deviation, and probability confidence intervals of 10, 50 and $90 \%$. The Heat in Place method yields a total mean estimate of 659 MWe distributed among the 9 geothermal systems, with a mean standard deviation of 49 MWe. The three Indicated systems yield a total value of 119 MWe with a standard deviation of 154 MWe. Of this systems, Apacheta and Tolhuaca are estimated to reach 99 and 70 MWe respectively. On the other hand, El Tatio yields only 56 MWe, because of its low reservoir thickness. La Torta, and Cordón Caulle have the highest estimated power output with Inferred category, reaching 128, and 97 MWe, respectively. The remaining systems, Puchuldiza, Tinguiririca, Mariposa (Laguna Del Maule), and Nevados de Chillán, yield intermediate values of 63, 54, 58, and 32 MWe, respectively (Table 2).

\subsection{Highly Probable Resource Areas}

Geothermal plays where geophysical surveys indicate the existence of a geothermal reservoir, or geothermometry suggests high temperature associated with a deep reservoir are ranked as highly probable resource areas (Table 3). Each geothermal play is described below.

\section{Tacora}




\begin{tabular}{|c|c|c|c|c|c|c|c|c|c|c|}
\hline \multirow{2}{*}{$\begin{array}{l}\text { System } \\
\text { Name }\end{array}$} & \multicolumn{2}{|c|}{ Location } & \multirow{2}{*}{$\begin{array}{l}\text { Area } \\
K m^{2}\end{array}$} & \multirow{2}{*}{$\begin{array}{c}\text { Thickness } \\
\text { m }\end{array}$} & \multirow{2}{*}{$\begin{array}{c}\text { Temperature } \\
{ }^{\circ} \mathrm{C}\end{array}$} & \multicolumn{2}{|c|}{ Results [MWe] } & \multicolumn{3}{|c|}{ Fit to distribution $[\mathrm{MWe}]$} \\
\hline & Lat. & Long. & & & & Mean & Std & $\mathrm{P} 10$ & $\mathrm{P} 50$ & P90 \\
\hline${ }^{1}$ Apacheta & 21.84 & 68.15 & $4-25$ & $880-1120$ & $212-250-256$ & 99 & 58 & 185 & 81 & 72 \\
\hline${ }^{1}$ El Tatio & 22.33 & 68.01 & $11.5-30$ & $150-430-650$ & $213-250-260$ & 59 & 32 & 105 & 51 & 25 \\
\hline${ }^{1}$ Tolhuaca & 38.31 & 71.66 & $4-8$ & $1000-1400$ & $250-280-300$ & 70 & 30 & 110 & 69 & 33 \\
\hline${ }^{2}$ Puchuldiza & 19.41 & 68.98 & $10-28$ & $600-1000$ & $200-250-270$ & 63 & 44 & 127 & 52 & 13 \\
\hline${ }^{2}$ La Torta & 22.42 & 67.97 & $15-25$ & $650-2000$ & $240-270$ & 128 & 89 & 256 & 107 & 27 \\
\hline${ }^{2}$ Tinguiririca & 34.85 & 70.38 & $5-25$ & $500-1000$ & $210-300$ & 54 & 45 & 117 & 42 & 9 \\
\hline${ }^{2}$ Mariposa & 36.06 & 70.53 & $9-23$ & $500-1000$ & $210-300$ & 58 & 43 & 120 & 47 & 11 \\
\hline${ }^{2}$ Nv. de Chillán & 36.90 & 71.40 & $6-15$ & 500-1000 & $220-260$ & 32 & 23 & 66 & 27 & 7 \\
\hline${ }^{2}$ Cordón Caulle & 40.49 & 72.16 & $8-20$ & $500-2000$ & $240-300$ & 97 & 76 & 203 & 77 & 17 \\
\hline Total & & & & & & 659 & 439 & 1290 & 548 & 180 \\
\hline
\end{tabular}

Table 2: Geothermal systems selected for the assessment of Indicated and Inferred Resource. Categories: ${ }^{1}$ Indicated; ${ }^{2}$ Inferred. Minimum, most likely and maximum values for the area, thickness and temperature of the reservoir are included. Mean electrical power output (MWe), standard deviation after 100,000 Monte Carlo iterations and 10-50-90\% confidence interval after fitting the results to Birnbaum Saunders (Indicated) and Weibull (Inferred) probability distribution. Geographic coordinates WGS84, zone $18-19^{\circ} \mathrm{S}$.

The Tacora geothermal prospect is associated with the 5,980 m high volcano with the same name close to the Chile-Peru international boundary. This geothermal prospect is characterized by intense fumarolic activity and with extensive, white colored, superficial alteration areas along the NW and W flanks of the volcanic structure. Chemical and isotopic compositions of the main carbon species are interpreted to indicate the presence a deep geothermal reservoir with temperatures of $270-310^{\circ} \mathrm{C}$ (Capaccioni et al., 2011).

\section{Colpitas}

The Colpitas geothermal prospect is located in the northernmost part of Chile in the Arica and Parinacota region. The area is characterized by volcanosedimentary sequences ranging in age from Miocene to Holocene, with at least 3 nearby active volcanoes. Thermal springs are located at the bottom of a wide basin, with spring water temperatures ranging from 28 to $55^{\circ} \mathrm{C}$ and a total discharge of $10 \mathrm{l} / \mathrm{s}$. $\mathrm{Na} / \mathrm{K}$ geothermometry suggests equilibration temperatures higher than $200^{\circ} \mathrm{C}$. A 3-D MT study shows a conductive area $(3-8 \Omega \mathrm{m})$ of several tens of $\mathrm{km}^{2}$ interpreted as the clay cap of an inferred geothermal reservoir 


\begin{tabular}{|c|c|c|c|c|}
\hline Name & Lat & Lon & Survey & Ref. \\
\hline Tacora & 17.70 & 69.80 & $\begin{array}{l}\text { Chemical and isotopic assessment of } \\
\text { gas emissions. }\end{array}$ & 1 \\
\hline Colpitas & 17.95 & 69.45 & $\begin{array}{l}\text { 3-D MT geophysical survey; Chemical } \\
\text { assessment of hot water discharges. }\end{array}$ & 5 \\
\hline Surire & 18.92 & 68.06 & $\begin{array}{l}\text { Chemical and isotopic assessment of } \\
\text { gas emissions and water discharges. }\end{array}$ & $1,4,10$ \\
\hline Pampa Lirima & 19.85 & 68.90 & $\begin{array}{l}\text { Geophysical survey; water and gas } \\
\text { geothermometry; Exploratory wells. }\end{array}$ & $4,6,12$ \\
\hline Irruputuncu & 20.71 & 68.59 & $\begin{array}{l}\text { MT,TDEM and ZTEM geophysical } \\
\text { surveys; Chemical and isotopic assess- } \\
\text { ment of gas emissions and water dis- } \\
\text { charges. }\end{array}$ & 9,11 \\
\hline Olca & 20.95 & 68.48 & $\begin{array}{l}\text { Geophysical survey; Chemical and iso- } \\
\text { topic assessment of gas emissions and } \\
\text { water discharges. }\end{array}$ & $1,2,3,11$ \\
\hline Juncalito & 26.51 & 68.82 & $\begin{array}{l}\text { Geophysical survey; gas geothermome- } \\
\text { try; exloratory wells. }\end{array}$ & 10,13 \\
\hline Sierra Nevada & 38.57 & 71.62 & $\begin{array}{l}\text { Geophysical survey; shallow ex- } \\
\text { ploratory wells. }\end{array}$ & 8 \\
\hline
\end{tabular}

Table 3: Highly probable resource areas and geothermal related surveys in the Chilean Andes. Geographic coordinates WGS84 zones $18-19^{\circ} \mathrm{S}$. 1 Cusicanqui (1979); 2 De Silva \& Francis (1991); 3 González-Ferrán (1995); 4 Tassi et al. (2010); 5 Aguirre et al. (2011); 6 Arcos et al. (2011); 7 Capaccioni et al. (2011); 8 Muñoz et al. (2011); 9 Reyes et al. (2011); 10 Risacher et al. (2011); 11 Tassi et al. (2011); 12 Legault et al. (2012); 13 Garcia (2014)

(Aguirre et al. 2011).

\section{Surire}

The Surire geothermal prospect is located south of the Surire salt deposits near the Polloquere volcano. Conventional aqueous geothermometers cannot be used because of the salt deposits (Risacher et al. 2011). Nevertheless, silica geothermometry indicates equilibrium temperatures ranging from $150-180^{\circ} \mathrm{C}$ (Cusicanqui, 1979). The gas composition indicates medium to high equilibrium temperatures $\left(>200^{\circ} \mathrm{C}\right)$, suggesting interactions of deeply circulating and shallow water (Tassi et al., 2010). 


\section{Pampa Lirima}

The Pampa Lirima geothermal project is located in the Altiplano of northern Chile, within the Central Andes Volcanic chain. The geochemical features of thermal water and gas discharges at Pampa Lirima are typical of fluids that have evolved within shallow aquifers; therefore low temperature aquifers may mask any signal of deep fluids (Tassi et al. 2010, Achurra, 2011). An MT/TDEM geophysical survey was carried out at Pampa Lirima, revealing a large conductive anomaly interpreted as a deep geothermal reservoir (Arcos et al. , 2011), although this preliminary conclusion is subject to further exploration. In addition, ZTEM inversion images appear to agree very well with the MT data, including the presence of a conductive layer at $>500 \mathrm{~m}$ below the Pampa Lirima valley (Legault et al., 2012).

\section{Irruputuncu}

Irruputuncu is a geothermal prospect located near the southeastern edge of the Tarapacá region, in northern Chile, east of the Doña Ines de Collahuasi copper mine, the owner of the geothermal exploration concession. Acid sulphate hot springs discharge at the base of the Irruputuncu dacitic stratovolcano (Reyes et al. 2011). A 3-D inversion of TEM-MT data indicates two conductive layers separated by a resistive zone. Beneath the conductive layers lies a resistive structure, interpreted as a high temperature geothermal reservoir, (Reyes et al. 2011). Two slim holes drilled west of the Irruputuncu volcano (800 and 1,430 $\mathrm{m}$ depth) encountered bottom hole temperatures of $150^{\circ} \mathrm{C}$ and $195^{\circ} \mathrm{C}$ (at 3,350 and 3,000 m.a.s.l., respectively) and record an argillic alteration assemblage. Temperature profiles were conductive and TEM-MT data suggests a potential deep reservoir temperature up to $220^{\circ} \mathrm{C}$ (Reyes et al., 2011).

\section{Olca}

Olca stratovolcano forms part of a $20 \mathrm{~km}$ long, EW-oriented volcanic chain that includes Paruma and Michincha volcanoes (De Silva \& Francis, 1991 González-Ferrán, 1995). The Olca geothermal prospect is characterized by a scarcity of superficial manifestations, as fumaroles are only found at the volcano crater, and a single warm spring is located at the base of the volcano. 

Groundwater exploration wells $(<700 \mathrm{~m})$ drilled at the base of the Olca volcano revealed an extensive clay-cap and temperatures up to $70^{\circ} \mathrm{C}$. Beneath this clay-cap, there is a high resistivity zone interpreted to result from high temperature alteration in the geothermal reservoir (Reyes et al. 2011). He, $\delta{ }^{18} \mathrm{O}$ and $\delta \mathrm{D}$ isotopic signature of the fumaroles suggests a mixing process between magmatic and hydrothermal sources. Gas geothermometry suggests equilibrium temperatures of 280 to $400{ }^{\circ} \mathrm{C}$ (Tassi et al. 2011).

\section{Juncalito geothermal area}

The Juncalito geothermal prospect is located in the Claudio Gay Cordillera, at the southern end of the CVZ, between Miocene eroded volcanic centers to the west, and Pliocene to Holocene volcanic centers to the east. An MT survey performed in 2012 shows a $2 \mathrm{~km}$ thick low resistivity anomaly, interpreted as the clay cap $(>16 \Omega \mathrm{m})$ above an inferred geothermal reservoir $(\sim 100 \Omega \mathrm{m})$. The geology and structural setting points to a N-S elongated shape for the reservoir (Garcia, 2014). Geothermometers must be used with extreme caution due to probable salt contamination (Risacher et al. 2011).

\section{Sierra Nevada geothermal area}

The Sierra Nevada geothermal system is associated with the similarly named Pleistocene-Holocene volcano in the Araucanía region of Chile. There are surface manifestations extending on the N and NW flanks of the volcano. Gas compositions of fumaroles suggest a high enthalpy, liquid dominated reservoir with an equilibrium temperature of $\sim 215^{\circ} \mathrm{C}$ (Muñoz et al. 2011). Further geophysical studies are essential to constrain the depth and dimensions of the inferred geothermal reservoir.

\subsection{Interest areas}

Based on geothermal exploration at a regional scale (Días, 1983; Hauser 1989, 1997, Peréz, 1999, Risacher et al. 2011) and surface geothermal features, the interest areas are summarized in Tab. 4

\begin{tabular}{llll} 
Name & Lat & Long & Geothermal feature \\
\hline
\end{tabular}




\begin{tabular}{|c|c|c|c|c|}
\hline Jurase & 18.20 & 69.53 & $\begin{array}{l}\text { Hot springs temperature } 65^{\circ} \mathrm{C} \text {; hy- } \\
\text { drothermal alteration; and silica sin- } \\
\text { ters. }\end{array}$ & $1,3,5$ \\
\hline Berenguela & 19.25 & 69.18 & Hot springs temperature $58^{\circ} \mathrm{C}$. & 1,3 \\
\hline Quitatiri & 19.34 & 69.50 & Hot springs temperature $87^{\circ} \mathrm{C}$. & 1,3 \\
\hline Chimisa & 19.38 & 69.29 & Hot springs temperature $90^{\circ} \mathrm{C}$. & $1,3,5$ \\
\hline Laguna Churicollo & 19.55 & 68.95 & Hot springs temperature $90^{\circ} \mathrm{C}$. & 1,3 \\
\hline Mamiña & 20.07 & 69.21 & Hot springs temperature $52^{\circ} \mathrm{C}$. & $1,3,5$ \\
\hline Aguas Calientes & 23.13 & 67.43 & Hot springs temperature $50^{\circ} \mathrm{C}$. & $1,3,5$ \\
\hline El Toro & 29.91 & 70.05 & Hot springs temperature $60^{\circ} \mathrm{C}$. & 1,3 \\
\hline Colina & 33.83 & 69.98 & Hot springs temperature $50^{\circ} \mathrm{C}$. & 3 \\
\hline Termas del Flaco & 34.95 & 70.43 & Hot springs temperature $77^{\circ} \mathrm{C}$. & 3 \\
\hline El Azufre & 35.32 & 70.54 & Hot springs temperature $70^{\circ} \mathrm{C}$. & 3 \\
\hline El Llolli & 35.37 & 70.58 & Hot springs temperature $95^{\circ} \mathrm{C}$. & 3 \\
\hline El Colorado & 35.41 & 70.52 & Hot springs temperature $75^{\circ} \mathrm{C}$. & 3 \\
\hline Tigre Naciente & 35.47 & 70.51 & Hot springs temperature $65^{\circ} \mathrm{C}$. & 3 \\
\hline Estero El Volcán & 35.50 & 70.76 & Hot springs temperature $95^{\circ} \mathrm{C}$. & 3 \\
\hline Descabezado Chico & 35.53 & 70.54 & Hot springs temperature $80^{\circ} \mathrm{C}$. & 3 \\
\hline Baños de la Turbia & 36.29 & 71.17 & Hot springs temperature $50^{\circ} \mathrm{C}$. & 3 \\
\hline Baños de Longaví & 36.35 & 71.14 & Hot springs temperature $81^{\circ} \mathrm{C}$. & 3 \\
\hline San Lorenzo & 36.76 & 71.40 & Hot springs temperature $60^{\circ} \mathrm{C}$. & 3 \\
\hline Aillin & 37.54 & 71.38 & $\begin{array}{l}\text { Hot springs temperature } 93^{\circ} \mathrm{C} \text {; exten- } \\
\text { sive hydrothermal alteration. }\end{array}$ & 3 \\
\hline Quilaquín & 37.60 & 71.40 & Hot springs temperature $75^{\circ} \mathrm{C}$. & 3 \\
\hline Emanuel & 37.60 & 71.28 & Hot springs temperature $54^{\circ} \mathrm{C}$. & 3 \\
\hline Copahue & 37.82 & 71.16 & Hot springs temperature $93^{\circ} \mathrm{C}$. & 3 \\
\hline Avellano & 37.99 & 71.53 & Hot springs temperature $81^{\circ} \mathrm{C}$. & 3,5 \\
\hline Manzanar & 38.46 & 71.71 & Hot springs temperature $52^{\circ} \mathrm{C}$. & 3,5 \\
\hline Balboa & 38.96 & 71.71 & Hot springs temperature $67^{\circ} \mathrm{C}$. & 3,5 \\
\hline Huife & 39.22 & 71.66 & Hot springs temperature $60^{\circ} \mathrm{C}$. & 3 \\
\hline Panqui & 39.25 & 71.53 & Hot springs temperature $50^{\circ} \mathrm{C}$. & 3 \\
\hline Geométricas & 39.50 & 71.87 & Hot springs temperature $72^{\circ} \mathrm{C}$. & $3,4,5$ \\
\hline Coñaripe & 39.63 & 71.92 & Hot springs temperature $62^{\circ} \mathrm{C}$. & 3,4 \\
\hline Liquiñe & 39.74 & 71.84 & Hot springs temperature $82^{\circ} \mathrm{C}$. & 3,4 \\
\hline Hipolito Muñoz & 39.76 & 71.79 & Hot springs temperature $85^{\circ} \mathrm{C}$. & 3,4 \\
\hline Oporto & 40.14 & 71.99 & Hot springs temperature $60^{\circ} \mathrm{C}$. & 3,4 \\
\hline Cupido & 40.15 & 71.91 & Hot springs temperature $80^{\circ} \mathrm{C}$. & 3,4 \\
\hline Chihuio & 40.19 & 71.93 & Hot springs temperature $82^{\circ} \mathrm{C}$. & $3,4,5$ \\
\hline
\end{tabular}




\begin{tabular}{|c|c|c|c|c|}
\hline La Esperanza & 40.34 & 71.82 & Hot springs temperature $60^{\circ} \mathrm{C}$. & 3,4 \\
\hline Puyehue & 40.71 & 72.32 & Hot springs temperature $75^{\circ} \mathrm{C}$. & $3,4,5$ \\
\hline Rupanco & 40.86 & 72.22 & Hot springs temperature $63^{\circ} \mathrm{C}$. & $3,4,5$ \\
\hline El Callao & 40.98 & 72.16 & Hot springs temperature $59^{\circ} \mathrm{C}$. & 3,4 \\
\hline Las Juntas & 41.25 & 72.04 & Hot springs temperature $73^{\circ} \mathrm{C}$. & 3,4 \\
\hline Cayetué & 41.30 & 72.20 & Hot springs temperature $65^{\circ} \mathrm{C}$. & 3,4 \\
\hline Cochamó & 41.36 & 72.32 & Hot springs temperature $70^{\circ} \mathrm{C}$. & 3 \\
\hline Llancahue & 42.07 & 72.51 & Hot springs temperature $52^{\circ} \mathrm{C}$. & 3 \\
\hline Cahuelmó & 42.26 & 72.38 & Hot springs temperature $84^{\circ} \mathrm{C}$. & 2,3 \\
\hline Michinmahuida & 42.96 & 72.39 & Hot springs temperature $65^{\circ} \mathrm{C}$. & 2,3 \\
\hline Río Frío & 43.47 & 72.47 & Hot springs temperature $70^{\circ} \mathrm{C}$. & 2,3 \\
\hline Puerto Bonito & 43.95 & 72.73 & Hot springs temperature $70^{\circ} \mathrm{C}$. & 2,3 \\
\hline Puyuhapi & 44.41 & 72.64 & Hot springs temperature $80^{\circ} \mathrm{C}$. & 2,3 \\
\hline Puerto Peréz & 45.24 & 70.21 & Hot springs temperature $90^{\circ} \mathrm{C}$. & 2,3 \\
\hline Aguas Calientes & 45.42 & 73.03 & Hot springs temperature $65^{\circ} \mathrm{C}$. & $2,3,5$ \\
\hline Contreras & 45.44 & 73.11 & Hot springs temperature $68^{\circ} \mathrm{C}$. & 2,3 \\
\hline Quitralco & 45.58 & 73.38 & Hot springs temperature $65^{\circ} \mathrm{C}$. & 2,3 \\
\hline Estero Negro & 45.69 & 72.33 & Hot springs temperature $60^{\circ} \mathrm{C}$. & 3 \\
\hline Huemules & 45.87 & 73.29 & Hot springs temperature $60^{\circ} \mathrm{C}$. & 3 \\
\hline Cupquelán & 45.96 & 73.39 & Hot springs temperature $60^{\circ} \mathrm{C}$. & 3 \\
\hline Huiña & 46.31 & 72.81 & Hot springs temperature $55^{\circ} \mathrm{C}$. & 3 \\
\hline Caleta Román & 46.06 & 75.51 & Hot springs temperature $65^{\circ} \mathrm{C}$. & 3 \\
\hline
\end{tabular}

Table 4: Interest Area locations and geothermal features in the Chilean Andes.

References in right column. Geographic coordinates WGS84 zones $18-19^{\circ} \mathrm{S}$.

1 Días (1983); 2 Hauser (1989); 3 Hauser (1997); 4 Peréz (1999); 5 Risacher et al. (2011)

\section{Discussion}

The experience of recent decades, has shown that the Heat in Place method is usually biased high. The tendency to overestimate the potential of geothermal prospects, in particular, has led to the reduced credibility of the method (Grant 2015). Much of the problem lies in the estimation of the recovery factor, the proportion of the resource that can actually be exploited. This factor cannot be determined without further evaluation of the reservoirs structural control and permeability heterogeneity (López \& Smith, 1996, Rowland \& Sibson, 2004). 
For low permeability systems (such as EGS), this recovery factor may be less than 0.02 (Grant \& Garg, 2012, Grant, 2015). Wilmarth \& Stimac (2015) estimated the power densities of 66 geothermal fields above 10 MWnet with more than 5 years of production history. Their work suggests that volcanic arc systems tend to be moderate to high-temperature and have moderate to high power densities (5-15 MWe $\left./ \mathrm{km}^{2}\right)$. Wilmarth \& Stimac (2015), and references therein, state that the fraction of the geothermal anomaly determined from low resistivity and thermal area that may eventually be developed is typically on the order of 0.5 , but may range from 0 to more than 1 . In this work we apply the power density method to an areal extent corresponding to half of the conductive anomaly. Fig. 7 (Left) depicts a comparison with results after applying the power density method to each system. Values obtained in Apacheta, La Torta, Tolhuaca, and Cordón Caulle correlate with a power density equivalent of $\sim 8$ to $15 \mathrm{MWe} / \mathrm{km}^{2}$, the remaining systems correlate nicely within a range of 4 to 5 $\mathrm{MWe} / \mathrm{km}^{2}$ suggesting that Andean systems might hold a much higher power potential if a best case scenario is achieved. Although the volume method provides a means of estimating the heat content of a geothermal reservoir, it does not explicitly predict the reservoir permeability (Williams et al., 2008). The structural setting in the Chilean volcanic arc is dominantly compressive (Fig. 1), but with varying complexities regarding each system local context. This variability is a source of uncertainty that must be taken into account. Puchuldiza, Apacheta, El Tatio/La Torta and Cordón Caulle are graben-related geothermal areas near an active volcanic arc. These systems show extensive superficial features, suggesting the occurrence of medium to high permeability. On the other hand, volcanic related systems like Tinguiririca, Mariposa, Nevados de Chillán and Tolhuaca are highly influenced by episodic re-shearing events. The nature of permeability in these areas is still a matter of debate. Further studies regarding permeability in Andean systems is highly recommended in order to understand its influence on the recovery factor.

Published data from 94 geothermal plants (Zarrouk \& Moon, 2014) helps to constrain single flash plants efficiency, and new models for the recovery of heat 

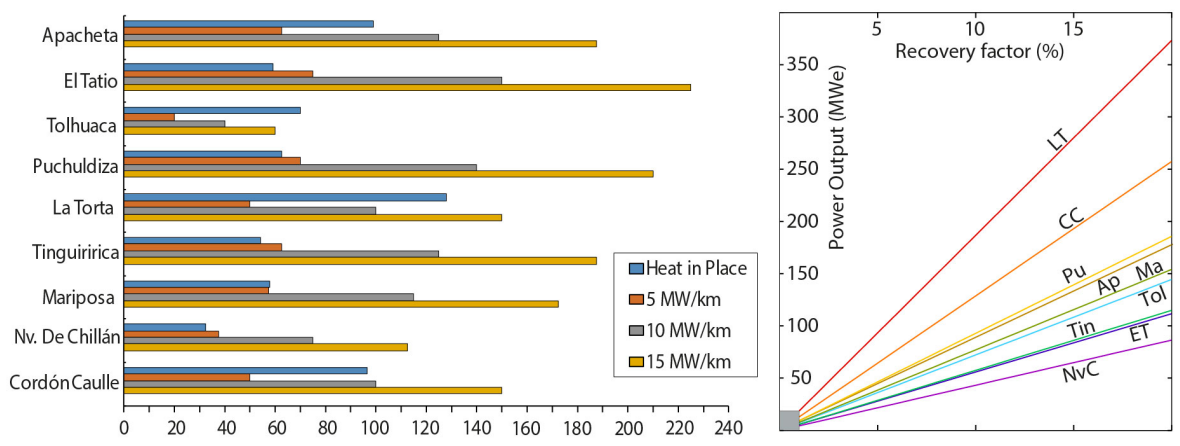

Figure 7: Left: Tornado diagram comparing results of this work with the power density method applied to the half of the areal extend of conductive anomaly. Right: Recovery factor sensitivity test for each system.

from heterogeneous, fractured reservoirs (Williams et al. 2008) provide a physically realistic basis for evaluating the production potential of natural geothermal reservoirs. Calculations are based upon recovery and conversion factors from single flash and dry steam power plants (Zarrouk \& Moon, 2014), since this is the type of power plant installed at a newly developed high temperature geothermal fields $(>200)$. Once the single flash steam power plant is running, DiPippo (2012a) recommends the installation of a double flash steam power plant in order to produce 15-25\% more power output for the same geothermal fluid conditions. Many plants often include both flash and binary systems to maximize electrical power generation. Nevertheless, an economic analysis is required for each individual system in order to properly address this issue.

Apacheta, La Torta, Tinguiririca, and Mariposa encompass extensive superficial features, suggesting the presence of large systems. Estimated volume and temperature of these areas show a high variability. For large geothermal systems, variation of temperature causes a great uncertainty in available energy. As a result, estimated power output for large systems show a higher standard deviation (Table 2).

The electrical anomaly, recorded by MT or TEM surveys, is usually interpreted as a result of successive alteration processes, which are part of the 
geothermal system evolution. Those processes can migrate over time. Therefore, the areal extent of the geothermal system inferred from the dimension of the clay cap may be overestimated, because there are no guarantees of geothermal fluid below the clay cap (e.g., the clay cap could correspond to a fossil system).

Temperature estimation can be a major source of uncertainty issues. If the up-flow zone has not been reached by exploratory wells, there is a chance temperatures can be underestimated. On the other hand, the application of geothermometers can lead to gross overestimation if they are not interpreted with caution.

Indicated and Inferred systems can be grossly classified into high and medium potential power-producing systems. Apacheta, La Torta and Cordón Caulle yield values of 99, 128 and 97 MWe respectively. The remaining systems (Nv. De Chillán, Tinguiririca, Mariposa, El Tatio and Tolhuaca in increasing order) range from 32 to $70 \mathrm{MWe}$, consistent with mean production values for volcanichosted geothermal systems (e.g. Zarrouk \& Moon, 2014, and references therein).

The heat source in El Tatio/La Torta and Puchuldiza remains unclear. It is necessary to consider the combined influence of volcanic convection dominated systems (Moeck, 2014), yet with a high influence of a regional heat flow anomaly. Geophysical surveys in El Tatio and La Torta suggests both systems share the same deep geothermal reservoir (Cumming et al. 2002), and are the largest Inferred system in the Chilean Andes, yielding 187 MWe with a standard deviation of 121 MWe. Additionally, the Sol de la Mañana geothermal field lies just $20 \mathrm{~km}$ east, on the east edge of the Pre-Altiplanic Cordillera, supporting the hypothesis of deep, high temperature reservoirs emplaced along this segment of the arc. Deep drilling and an EGS approach can be assessed as an alternative for several mining projects located along the CVZ whose energetic needs are consistent with geothermal high plant factors.

Many Andean systems present fluids of an acid nature which can be problematic due to the impact in costs and maintenance. Nevertheless, the resource can be exploited by binary plants (DiPippo, 2008). Therefore, despite there 
is no consideration about geothermal fluid composition, the geothermal power potential is still valid even in the case of problematic geothermal fluids.

\section{Conclusion}

We gathered and ranked geothermal exploration data available in the literature, establishing categories of Measured, Indicated, and Inferred geothermal resource. We then applied, numerical methods to 9 high enthalpy reservoirs $\left(>200^{\circ} \mathrm{C}\right)$ in the Chilean Andes. In addition, 8 areas are highlighted as highly favorable, based on geological, geochemical and/or geophysical surveys. Furthermore, 57 geothermal areas are considered as potential high enthalpy geothermal resources, suggesting there are many undiscovered geothermal systems in the Chilean Andes.

Based on available published geological, geochemical and geophysical evidence, the total Indicated resource is 228 MWe with a Standard deviation of 119 MWe. Inferred resources reach 431 MWe with a Standard deviation of 321 MWe, adding up to 659 MWe among medium (6) and large systems (3) in the Chilean Andes. This total estimated power potential is equivalent to $\sim 4.4 \%$ of the total installed electric capacity in Chile.

Although volumetric methods provide a means of estimating the heat content of a geothermal reservoir, it does not explicitly predict the power potential. It does allow for a gross estimate and a comparative evaluation of the different geothermal prospects. Comparison with values obtained through the power density method leads to a better understanding of the full uncertainty of resource capacities.

Despite the high degree of geologic uncertainty, finite element modeling is highly recommended for Indicated and Inferred systems (Tab2). This approach provides a more rigorous way to evaluate and understand conceptual models and system thermodynamics. 


\section{Acknowledgments}

This work has been supported by the FONDAP/CONICYT Project number 15090013 (Centro de Excelencia en Geotermia de los Andes, CEGA) and Departamento de Geología, FCFM, Universidad de Chile. P. Dobson was supported by Lawrence Berkeley National Laboratory under U.S. Department of Energy, Assistant Secretary for Energy Efficiency and Renewable Energy, Geothermal Technologies Office, under the U.S. Department of Energy Contract no. DEAC02-05CH11231. The authors would especially like to thank to Dra. Jennifer Blank and two anonymous reviewers for their valuable comments.

\section{References}

Achurra, L. (2011). Estudio hidrogeoquímico sobre la interaccin de aguas subterráneas profundas y someras en Pampa Lirima, Norte de Chile. Master thesis Universitat Politècnica de Catalunya Barcelona.

Aguirre, I., Clavero, J., Simmons, S., Giavelli, A., Mayorga, C., \& Soffia, J. (2011). Colpitas-a new geothermal project in Chile. In Geothermal Resources Council Transactions (pp. 1141-1145). California: Geothermal Resources Council volume 35 .

Aldrich, M., Laughlin, A., \& Gambill, D. (1981). Geothermal Resource Base of the World: A revision of the Electrical Power Research Institute's estimate. Technical Report Electrical Power Research Institute.

Aravena, D., \& Lahsen, A. (2012). Assessment of exploitable geothermal resources using magmatic heat transfer method, Maule Region, Southern Volcanic Zone, Chile. In Geothermal Resources Council Transactions (pp. 1307-1313). California: Geothermal Resources Council volume 36.

Aravena, D., \& Lahsen, A. (2013). A geothermal favorability map of Chile, preliminary results. In Geothermal Resources Council Transactions. California: Geothermal Resources Council volume 37. 
Arcos, R., Clavero, J., Giavelli, A., Simmons, S., Aguirre, I., Martini, S., Mayorga, C., Pineda, G., Parra, J., \& Soffia, J. (2011). Surface exploration at Pampa Lirima geothermal project, central Andes of northern Chile. In Geothermal Resources Council Transactions (pp. 689-693). California: Geothermal Resources Council volume 35.

Capaccioni, B., Aguilera, F., Tassi, F., Darrah, T., Poreda, R., \& Vaselli, O. (2011). Geochemical and isotopic evidences of magmatic inputs in the hydrothermal reservoir feeding the fumarolic discharges of tacora volcano (northern Chile). Journal of Volcanology and Geothermal Research, 208, 77-85. URL: http://www.sciencedirect. com/science/article/pii/S0377027311002587, doi:http://dx.doi.org/ $10.1016 / j \cdot j v o l g e o r e s .2011 .09 .015$.

Cembrano, J., \& Lara, L. (2009). The link between volcanism and tectonics in the southern volcanic zone of the Chilean Andes: A review. Tectonophysics, 471, 96-113. URL: http://www.sciencedirect. com/science/article/pii/S0040195109001310 doi/http://dx.doi.org/ $10.1016 / j$.tecto.2009.02.038 Understanding stress and deformation in active volcanoes.

Cembrano, J., Lavenu, A., nez, G. Y., Riquelme, R., García, M., Hérail, G., \& González, G. (2007). Neotectonics. In T. Moreno, \& W. Gibbons (Eds.), The Geology of Chile. London: The Geological Society of London.

Clavero, J., Pineda, G., Mayorga, C., Giavelli, A., Aguirre, I., Simmons, S., Martini, S., Soffia, J., Arriaza, R., Polanco, E., \& Achurra, L. (2011). Geological, geochemical, geophysical and first drilling data from Tinguiririca geothermal area, central Chile. In Geothermal Resources Council Transactions (pp. 731-734). California: Geothermal Resources Council volume 35.

Cumming, W., Vieytes, H., Ramirez, C., \& Sussman, D. (2002). Exploration of the La Torta geothermal prospect, northern Chile. In Geothermal Resources 
Council Transactions (pp. 3-7). California: Geothermal Resources Council volume 26 .

Cusicanqui, H. (1979). Estudio geoquímico del área termal de Surire - provincia de Arica - I Región. Technical Report Comité Geotérmico CORFO Santiago.

De Silva, S., \& Francis, P. (1991). Volcanoes of the Central Andes. Berlin: Springer-Verlag.

Días, F. (1983). Present state of geothermal research and development in Chile. Technical Report Servicio Naciona de Geología y Minería Santiago.

DiPippo, R. (2008). Binary cycle power plants. In R. DiPippo (Ed.), Geothermal Power Plants (Second Edition) chapter 8. (pp. 157 - 189).

Oxford: Butterworth-Heinemann. (Second edition ed.). URL: http:// www.sciencedirect.com/science/article/pii/B9780750686204500137. doi:http://dx.doi.org/10.1016/B978-075068620-4.50013-7.

DiPippo, R. (2012a). Geothermal power generating systems. In R. DiPippo (Ed.), Geothermal Power Plants chapter 2. (pp. 79-80). Boston: Butterworth-Heinemann. (Third edition ed.). URL: http://www. sciencedirect.com/science/article/pii/B9780080982069000324 doi:http://dx.doi.org/10.1016/B978-0-08-098206-9.00032-4.

DiPippo, R. (2012b). Reservoir engineering. In R. DiPippo (Ed.), Geothermal Power Plants chapter 4. (pp. 49-77). Boston: n Butterworth-Heinemann. (Third edition ed.). URL: http://www. sciencedirect.com/science/article/pii/B978008098206900004X doi:http://dx.doi.org/10.1016/B978-0-08-098206-9.00004-X.

Emparán, C., Suárez, M., \& Muñoz, J. (1997). Hoja Curacautín: Regiones de la Araucanía y del Biobio. Number 71 in Carta Geológica de Chile. Santiago: Servicio Nacional de Geología y Minería. 105p - 1 map.

ENEL (2012). Cerro Pabellon Geothermal Project (Apacheta). Technical Report Enel, Latinoamérica (Chile) Ltda. 
ENG (2007). Estudio de impacto ambiental: Exploración geotérmica profunda Nevados de Chillán sector Valle de las Nieblas. Technical Report Empresa Nacional de Geotermia S.A.

Garcia, K. (2014). Aplicación del método magnetotelúrico en la exploración de un sistema geotermal, en la región de Atacama, Chile. Master's thesis Universidad de Chile Santiago. URL: http://tesis.uchile.cl/handle/ $2250 / 116320$.

Garg, S. K., \& Combs, J. (2010). Appropriate use of usgs volumetric heat in place method and monte carlo calculations. In Workshop on Geothermal Reservoir EngineeringStanford University (p. 7). Stanford, CA volume 34.

Garg, S. K., \& Combs, J. (2015). A reformulation of usgs volumetric "heat in place" resource estimation method. Geothermics, 55, 150 -158. URL: http: //www.sciencedirect.com/science/article/pii/S0375650515000280. doi:http://dx.doi.org/10.1016/j.geothermics.2015.02.004.

González-Ferrán, O. (1995). Volcanes de Chile. (First edition ed.). Santiago: Instituto Geográfico Militar.

Grant, M. (2015). Resource assessment, a review, with reference to the Australian Code. In Proceedings World Geothermal Congress. Melbourne.

Grant, M., \& Garg, S. (2012). Recovery factor for EGS. In Workshop on Geothermal Reservoir Engineering 37. Stanford University.

Hauser, A. (1989). Fuentes termales y minerales en torno a la Carretera Austral, regiones X-XI, Chile. Andean Geology, 16, 229-239.

Hauser, A. (1997). Catastro y catacterización de las fuentes de aguas minerales y termales de Chile. 50. Santiago: Servicio Nacional de Geología y Minería.

Hickson, C., Ferraris, F., Rodriquez, C., Sielfeld, G., Henriquez, R., Gislason, T., Selters, J., Benoit, D., White, P., Southon, J., Ussher, G., Charroy, J., Smith, A., Lovelock, B., Lawless, J., Quinliven, P., Smith, L., \& Yehia, R. 
(2011). The Mariposa geothermal system, Chile. In Geothermal Resources Council Transactions (pp. 817-825). California: Geothermal Resources Council volume 35 .

Iriarte, S. (2013). Exploración geotérmica proyecto Tolhuaca.

JICA (1979). Informe preliminar segunda fase JICA - Proyecto de desarrollo del campo geotérmico de Puchuldiza. Technical Report Comité Geotérmico CORFO Santiago.

Lahsen, A. (1976). Geothermal exploration in Northern Chile - Summary. In Circum-Pacific Energy and Mineral Resources (pp. 169-175). The American Association of petroleum Geologists.

Lahsen, A. (1978). Evaluación de los resultados de la exploración del campo geotérmico de Puchuldiza I Región Tarapacá. Technical Report Comité Geotérmico CORFO Santiago.

Lahsen, A. (1986). Origen y potencial de energía geotérmica en los Andes de Chile. Technical Report Geología y Recursos Minerales de Chile, Universidad de Concepción Concepción.

Lahsen, A. (1988). Chilean geothermal resources and their possible utilization. Geothermics, 17, 401 - 410. URL: http://www. sciencedirect.com/science/article/pii/0375650588900685, doi:http: //dx.doi.org/10.1016/0375-6505(88)90068-5.

Lahsen, A., Muñoz, N., \& Parada, M. A. (2010). Geothermal Development in Chile. In World Geothermal Congress (pp. 25-29). Bali.

Lahsen, A., \& Trujillo, P. (1976). El campo geotermico de El Tatio, Chile. Proyecto Geotermico CORFO-ONU. Technical Report Corporación de Fomento de la Producción (CORFO) Santiago.

Lee, S., Simkin, T., \& Kimberly, P. (2010). Volcanoes of the World. (3rd ed.). Berkeley and Los Angeles, California: University of California Press. 
Legault, J., Lombardo, S., Zhao, S., Clavero, J., Aguirre, I., Arcos, R., \& Lira, E. (2012). ZTEM airborne AFMAG EM and ground geophysical survey comparisons over the pampa lirima geothermal field in northern Chile - a ) Z-axis tipper electromagnetic system. In Geothermal Resources Council Transactions (pp. 1001-1008). California: Geothermal Resources Council volume 36 .

Letelier, M. (1981). Geoqumica de las manifestaciones termales de Puchulduza y sus alrededores. Technical Report Comité Geotérmico CORFO Santiago.

Lira, E. (2011). Estudio de sismicidad, tomografía sísmica y modelo de física de rocas: Potencial sistema geotermal asociado al complejo volcánico Tinguiririca. Master's thesis Universidad de Chile Santiago.

López, D. L., \& Smith, L. (1996). Fluid flow in fault zones: influence of hydraulic anisotropy and heterogeneity on the fluid flow and heat transfer regime. $W a-$ ter Resources Research, 32, 3227-3235. doi:http://dx.doi.org/10.1029/ 96WR02101.

Lovekin, J. (2004). Geothermal inventory. Bulletin Geothermal Resources Council, 33, 242-244.

Melosh, G., Moore, J., \& Stacey, R. (2012). Natural reservoir evolution in the Tolhuaca geothermal field, southern Chile. In Workshop on Geothermal Reservoir Engineering. California volume 36 of SGP-TR-194.

Moeck, I. S. (2014). Catalog of geothermal play types based on geologic controls. Renewable and Sustainable Energy Reviews, 37, 867-882. URL: http://www.sciencedirect.com/science/article/ pii/S1364032114003578, doi:http://dx.doi.org/10.1016/j.rser.2014. 05.032 .

Moreno, H., \& Gardeweg, M. (1989). La erupción reciente en el Complejo Volcanico Lonquimay (diciembre 1988), Andes del Sur. Andean Geology, 16, 93-117. 
Muffler, L. (1979). Assessment of geothermal resources of the United States1978. Circular 790 U.S. Geological Survey.

Muffler, L., \& Cataldi, M. (1978). Assessment of geothermal resources of the United States - 1978. In L. Muffler (Ed.), Geological Survey Circular 790 (pp. 1-7). Arlington: U.S. Geological Survey.

Muñoz, J., \& Stern, C. (1988). The quaternary volcanic belt of the southern continental margin of south america: Transverse structural and petrochemical variations across the segment between $38^{\circ} \mathrm{S}$ and $39^{\circ} \mathrm{S}$. Journal of South American Earth Sciences, 1, 147-161. URL: http://www. sciencedirect.com/science/article/pii/0895981188900326. doi:http: //dx.doi.org/10.1016/0895-9811(88)90032-6.

Muñoz, M., Alam, A., Parada, M., \& Lahsen, A. (2011). Geothermal system associated with the Sierra Nevada volcano, Araucanía region, Chile. In Geothermal Resources Council Transactions (pp. 935-941). California: Geothermal Resources Council volume 35.

Nathenson, M. (1975). Physical factors determining the fraction of stored energy recoverable from hydrothermal convection systems and conduction-dominated areas. Open-File Report 75-525 U.S. Geological Survey.

Ortiz, M., Achurra, L., Cortés, R., Fonseca, A., Silva, C., \& Vivallos, J. (2008). Estudio geológico, geofísico e hidroquímico del sector Puchuldiza sur. Unpublished report Servicio Nacional de Geología y Minería Santiago. 1 map.

Pérez, P., Sánchez, P., Arancibia, G., Cembrano, J., Veloso, E., Lohmar, S., Stimac, J., Reich, M., \& Rubilar, J. (). Sampling and detailed structural mapping of veins, fault-veins and faults from Tolhuaca Geothermal System, southern Chile. In Congreso Geológico Chileno. Antofagasta volume 13.

Peréz, Y. (1999). Fuente de aguas termales de la Cordillera Andina del centrosur de Chile $\left(39-42^{\circ} \mathrm{S}\right)$. 54. Santiago: Servicio Nacional de Geología y Minería. 1 map 1:500,000. 
Procesi, M. (2014). Geothermal potential evaluation for northern Chile and suggestions for new energy plans. Energies, 7, 5444-5459. URL: http:

//www.mdpi.com/1996-1073/7/8/5444. doi:http://dx.doi.org/10.3390/ en7085444

Ramírez, C., \& Huete, C. (1981). Hoja Ollague, escala 1:250,000. Carta Geológica de Chile,. Santiago: Servicio Nacional de Geología y Minería. 47p -1 map.

Reyes, N., Vidal, A., Ramirez, E., Arnason, K., Richter, B., Steingrimsson, B., Acosta, O., \& Camacho, J. (2011). Geothermal exploration at Irruputuncu and Olca volcanoes: Pursuing a sustainable mining development in Chile. In Geothermal Resources Council Transactions (pp. 983-986). California: Geothermal Resources Council volume 35.

Risacher, F., Fritz, B., \& Hauser, A. (2011). Origin of components in chilean thermal waters. Journal of South American Earth Sciences, 31, 153-170. URL: http://www.sciencedirect.com/science/article/pii/ S0895981110000349. doi/http://dx.doi.org/10.1016/j.jsames.2010. 07.002 .

Rojas, E., Folguera, A., Zamora, G., Bottesi, G., \& Ramos, V. (2014). Structure and development of the andean system between $36^{\circ} \mathrm{S}$ and $39^{\circ} \mathrm{S}$.

Journal of Geodynamics, 73, 34-52. URL: http://www.sciencedirect. com/science/article/pii/S0264370713001336 doi/http://dx.doi.org/ $10.1016 / \mathrm{j} \cdot \mathrm{jog} .2013 .09 .001$

Rojas, G. (2013). Magnetotelúrica en el Complejo Volcánico Cordón Caulle. Bachelor thesis Universidad de Concepción.

Rosenau, M., Melnick, D., \& Echtler, H. (2006). Kinematic constraints on intra-arc shear and strain partitioning in the southern Andes between $38^{\circ} \mathrm{S}$ and $42^{\circ} \mathrm{S}$ latitude. Tectonics, 25. doi:http://dx.doi.org/10.1029/ 2005TC001943. 
Rowland, J., \& Sibson, R. (2004). Structural controls on hydrothermal flow in a segmented rift system, Taupo Volcanic Zone, New Zealand. Geofluids, 4, 259-283. doi:http://dx.doi.org/10.1111/j.1468-8123.2004.00091.x.

Sánchez, P., Morata, D., Lahsen, A., Aravena, D., \& Parada, M. A. (2011). Current status of Geothermal Exploration in Chile and the role of the New Andean Geothermal Center of Excellence (CEGA). In Geothermal Resources Council Transactions (pp. 1215-1218). California: Geothermal Resources Council volume 35 .

Sarmiento, Z., Ármannsson, H., Abanes, R., Marangunic, C., Ingimundarson, A., \& O'Ryan, R. (2010). Revisión de la ejecución del proyecto Perforación Geotérmica Profunda El Tatio, Fase I, Informe Final. Technical Report Comisión Nacional de Energía Chile.

Sepúlveda, F. (2005). El sistema Geotermico de Cordón Caulle: caracterización geológica y geoquímica. Ph.D. thesis Universidad de Chile.

Sepúlveda, F., \& Lahsen, A. (2003). Geothermal exploration in central-southern Chile (33-42 $\left.{ }^{\circ} \mathrm{S}\right)$. In Geothermal Resources Council Transactions (pp. 635638). Geothermal Resources Council volume 27.

Sepúlveda, F., Lahsen, A., \& Powell, T. (2007). Gas geochemistry of the cordón caulle geothermal system, southern Chile. Geothermics, 36, 389-420. URL: http://www.sciencedirect.com/science/article/pii/ S0375650507000533 doi http://dx.doi.org/10.1016/j.geothermics. 2007.05 .001

SERNAGEOMIN (2003). Mapa geológico de Chile: versión digital. Digital Geological Publishing, No. 4 (CD-ROM, version 1.0, 2003).

Tassi, F., Aguilera, F., Darrah, T., Vaselli, O., Capaccioni, B., Poreda, R., \& Huertas, A. D. (2010). Fluid geochemistry of hydrothermal systems in the Arica-Parinacota, Tarapacá and Antofagasta regions (northern Chile). Journal of Volcanology and Geothermal Research, 192, 1-15. URL: http: 
//www.sciencedirect.com/science/article/pii/S0377027310000405 doi:http://dx.doi.org/10.1016/j.jvolgeores.2010.02.006

Tassi, F., Aguilera, F., Vaselli, O., Darrah, T., \& Medina, E. (2011). Gas discharges from four remote volcanoes in northern Chile (Putana, Olca, Irruputuncu and Alitar): a geochemical survey. Annals of Geophysics, 54.

URL: http://www.annalsofgeophysics.eu/index.php/annals/article/ view/5173, doi/http://dx.doi.org/10.4401/ag-5173

Tassi, F., Martinez, C., Vaselli, O., Capaccioni, B., \& Viramonte, J. (2005). Light hydrocarbons as redox and temperature indicators in the geothermal field of El Tatio (northern Chile). Applied Geochemistry, 20, 2049-2062. URL: http://www.sciencedirect.com/science/article/ pii/S0883292705001599 doi:http://dx.doi.org/10.1016/j.apgeochem. 2005.07 .013

Tebbens, S., Cande, S., Kovacs, L., Parra, J., LaBrecque, J., \& Vergara, H. (1997). The Chile Ridge: A tectonic framework. Journal of Geophysical Research: Solid Earth (1978-2012), 102, 12035-12059. doi/http://dx.doi. org/10.1029/96JB02581

Tocchi, E. (1923). Il Tatio, ufficio geológico Larderello SpA. Umpublished Report.

Urzua, L., Powell, T., Cumming, W., \& Dobson, P. (2002). Apacheta, a new geothermal prospect in northern Chile. In Geothermal Resources Council Transactions (pp. 65-69). Geothermal Resources Council volume 26.

Vázquez, M., Nieto, F., Morata, D., Droguett, B., Carrillo-Rosua, F., \& Morales, S. (2014). Evolution of clay mineral assemblages in the Tinguiririca geothermal field, Andean Cordillera of central Chile: an $\{\mathrm{XRD}\}$ and hrtem-aem study. Journal of Volcanology and Geothermal Research, 282, 43-59. URL: http://www.sciencedirect. com/science/article/pii/S0377027314001760 doi/http://dx.doi.org/ $10.1016 / j \cdot$ jvolgeores.2014.05.022. 
830 White, D., \& Williams, D. (1975). Assessment of geothermal resources of the United States-1975. Circular 726 U.S. Geological Survey.

${ }_{832}$ Williams, C., Reed, M., \& Mariner, R. (2008). A review of methods applied by the US Geological Survey in the assessment of identified geothermal resources. Open-File Report U.S. Geological Survey.

Zarrouk, S. J., \& Moon, H. (2014). Efficiency of geothermal power 1) plants: A worldwide review. Geothermics, 51, 142-153. URL: http: //www.sciencedirect.com/science/article/pii/S0375650513001120 doi:http://dx.doi.org/10.1016/j.geothermics.2013.11.001. 